\title{
Population status and identification of potential habitats for the conservation of the Endangered black howler monkey Alouatta pigra in northern Chiapas, Mexico
}

\author{
Yadira M. Bonilla-SÁnChez, Juan Carlos Serio-Silva \\ Gilberto Pozo-MontuY and Nora BYNUM
}

\begin{abstract}
In the Mexican state of Chiapas the rainforest has been cleared, to make way for crops and extensive cattle ranching, at an annual rate of $12.4 \%$ since 2002 . The conservation status of the Endangered black howler monkey Alouatta pigra in these fragmented landscapes in northeastern Chiapas has not previously been examined. We therefore surveyed $A$. pigra populations in the municipality of Playas de Catazajá during 2004-2006 to obtain population and habitat data for this species in 115 fragments of remnant vegetation. A geographical information system was used to determine the variables (fragment size, and distances to the nearest fragment, human settlement and water body) that could be used to generate an index of habitat potential for A. pigra. We estimated a population of 659 individuals and a mean troop size of $5.0 \pm$ SE 2.3. The adult male:female ratio was $1: 1.4$, the adult female: juvenile ratio $1: 0.6$ and adult female:immature ratio $1: 0.8$. The index of habitat potential indicates that $12 \%$ of the fragments have a high conservation potential for $A$. pigra. This index is a valuable tool for evaluating the conservation status of this species and its habitat, and can be expanded to include additional variables, thus allowing for a more comprehensive assessment.
\end{abstract}

Keywords Alouatta pigra, black howler monkey, index of habitat potential, Playas de Catazajá, Mexico, population

\section{Introduction}

The rainforests of Mexico are biologically productive and I diverse ecosystems (Challenger, 1998) but are being transformed by human activity at an increasing rate. For example, the annual deforestation rate during 1990-2000 in north-eastern Chiapas, near the Palenque National Park,

Yadira M. Bonilla-Sánchez and Gilberto Pozo-Montuy División de Posgrado, Instituto de Ecología AC, Xalapa, Mexico

Juan Carlos Serio-Silva (Corresponding author) Departamento de Biodiversidad y Ecología Animal, Instituto de Ecología, AC, Apartado Postal 63, Xalapa, Veracruz 91000, Mexico. E-mail juan.serio@inecol.edu.mx

Nora Bynum Center for Biodiversity and Conservation, American Museum of Natural History, New York, USA

Received 20 February 2008. Revision requested 20 May 2008. Accepted 4 July 2008. was $12.4 \%$, in central Chiapas $4.5 \%$, and on the southern Yucatan Peninsula 7.7\% (Estrada et al., 2004; Cayuela, 2006; Serio-Silva et al., 2006). Deforestation has resulted in the local and regional extinction of plant and animal species, including the black howler monkey Alouatta pigra of Mesoamerica, specifically Mexico (Tabasco, Chiapas and the Yucatan Peninsula), Guatemala and Belize (Horwich, 1998; Pavelka, 2003; Estrada et al., 2004; Serio-Silva et al., 2006). A. pigra is protected by the laws of each Mesoamerican country in which it occurs (Mexico: Mexican Ecological Norms, NOM-059-SEMARNAT, 2001; Guatemala: Appendix II of the wildlife Red List, CONAP 2001; Belize: Wildlife Protection Act, WPA, 1982), and is categorized as Endangered on the IUCN Red List (IUCN, 2008) and listed in Appendix I of CITES (CITES, 2009).

Recent studies of A. pigra in Chiapas have highlighted the lack of information on the conservation status of the species in protected rainforests and fragmented sites (Estrada et al., 2002a, 2004; Van Belle \& Estrada, 2005). There are only a few studies of this species in fragmented sites in Mexico: in the Palenque National Park in the state of Campeche and in Balancan, Tabasco (Estrada et al., 2002b; Pozo-Montuy et al., 2008). Only in Belize, where the species has been studied in more detail, is there information on the impact of fragmentation, both anthropogenic and natural, on the demography, ecology, behaviour and physiology of A. pigra (Ostro et al., 2001; Horwich et al., 2001; Marsh, 2003; Pavelka, 2003; Pavelka et al., 2003).

Studies in fragmented landscapes report high densities of A. pigra compared to the density of the species in unfragmented rainforest. This may be the result of (1) the crowding of A. pigra into small fragments (an area effect), (2) the tolerance of these animals to habitat reduction, and/or (3) flexibility in diet (Estrada et al., 2002b; Pozo-Montuy et al., 2008). Under such conditions howler monkeys face the risk of increased parasite transmission as well as an overall increase in risk to their health because they have to descend to the ground and move between forest fragments to meet their nutritional needs (Stuart et al., 1990; Stoner, 1996; Ascencio et al., 2009).

The main questions that we address here are: (1) What is the population size and density of A. pigra in Playas de Catazajá, Chiapas? (2) How are troops distributed and what 
are the age and sex composition and size of the troops? (3) Which vegetation fragments are more suitable for the conservation of A. pigra in this region?

\section{Study area}

The municipality of Playas de Catazajá is in north-east Chiapas, Mexico, at an altitude of $20 \mathrm{~m}$. The site studied covers c. $621 \mathrm{~km}^{2}$ (Fig. 1). Playas de Catazajá is part of a system of wetlands in the Usumacinta River basin. The bloodwood tree Haematoxylon campechianum is typical of this region of low sub-perennial rainforest and riparian and secondary vegetation (Pennington \& Sarukhán, 1998). The remnant vegetation in Playas de Catazajá is mainly managed, secondary and riparian vegetation surrounded by a matrix of pastures.

\section{Methods}

A complete census of A. pigra was carried out in each of the 115 forest fragments in 46 ejidos (communal land for agriculture under the stewardship of rural inhabitants). We assumed that we are able to locate all A. pigra groups present in these small fragments. This was accomplished by a team of 3-4 people walking slowly to cover the entirety of each fragment; this method has been used by other authors working with Alouatta under similar conditions (Zunino et al., 2007; Pozo-Montuy et al., 2008). Surveys were conducted over 17 months (October 2004 to March 2006), from 06.00 to 17.00 . The ejidos were randomly selected from among the 52 ejidos in Playas de Catazajá, each of which contains 1-6 forest fragments. Each ejido was surveyed on consecutive days until all chosen fragments had been censused. Ejidos with 1-3 fragments were sampled in a single day, those with 4-5 fragments in 2 days and those with six fragments in up to 3 days.

When a troop of A. pigra was sighted the animals were observed for at least 30 minutes and the age/sex composition of the troop and any other features of note (e.g. body scars) recorded. Each fragment in which A. pigra was encountered was georeferenced using a global positioning system, and the data transferred to orthophotos $(1: 20,000)$ using the geographical information system ArcView v. 3.2 (ESRI, Redlands, USA). Collection of detailed information on each troop ensured that we did not repeat observations on individual troops. Density was calculated as the number of individuals in the total area surveyed (691.2 ha).

We drew distribution maps for A. pigra and identified habitats for conservation based on five factors that have been identified as important for the species in fragmented habitat (Marsh, 2003; Rodríguez-Toledo et al., 2003; AnzuresDadda \& Manson, 2007): vegetation type (recorded for each fragment visited: rainforest, riparian vegetation, secondary vegetation) and fragment size, and distances to the nearest fragment, human settlement and water body from fragment edge. Variables other than vegetation type were calculated using ArcView.

For fragments that contained A. pigra multiple linear regression was used to evaluate the relationship of abundance and troop size with area of fragment and distances to the nearest fragment, human settlement and water body. A non-parametric one-way ANOVA (Kruskall-Wallis) was used to identify any significant differences in these characteristics between fragments with and without $A$. pigra.

For each fragment inhabited by $A$. pigra we calculated an index of habitat potential (also known as the ecotourism

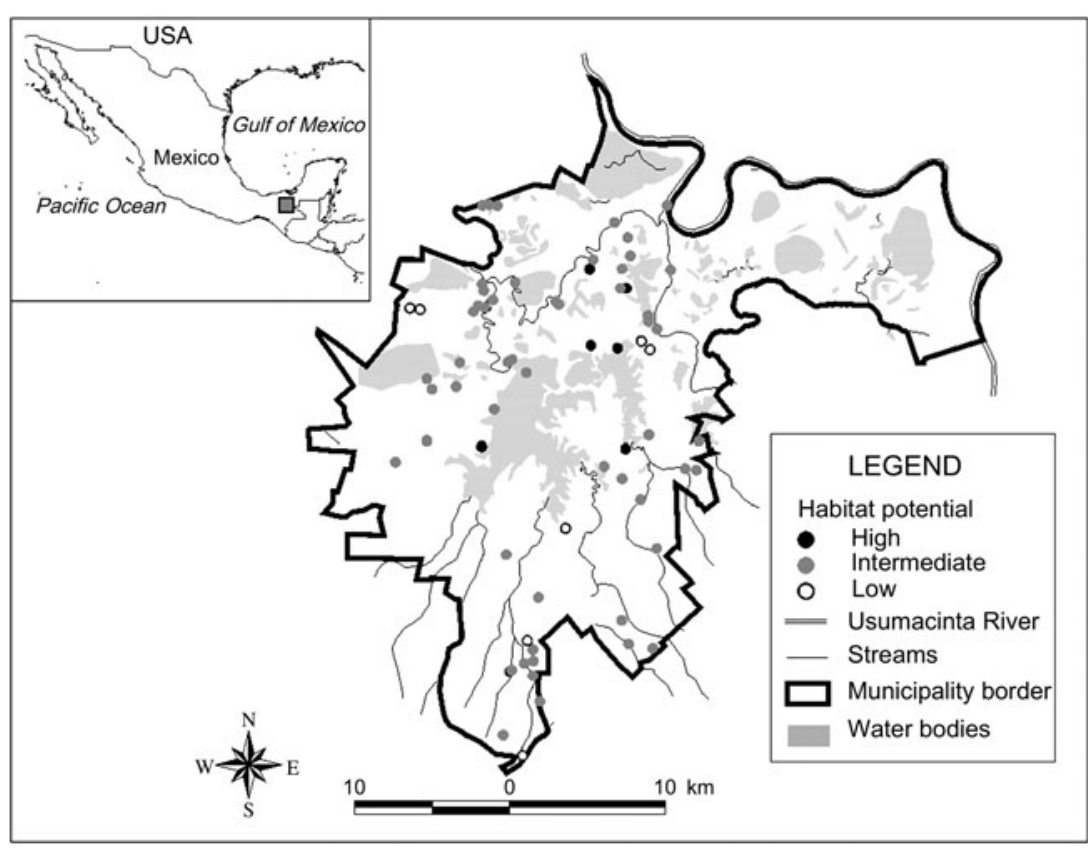

FIG. 1 The study area of Playas de Catazajá, Chiapas, illustrating the distribution of the studied forest fragments and the index of habitat potential (see text for details) for conservation of black howler monkey Alouatta pigra in Playas de Catazajá, Chiapas. The rectangle on the inset indicates the location of the main figure in Mexico. 
potential index; Berovides-Álvarez, 2000) for conservation. Each independent variable was scored in the range 1-3, where 3 represents the most favourable condition of the variable for conservation of the species, 1 the least favourable and 2 an intermediate condition (Table 1). These scores are summed for the five variables, giving an index with a potential range of 3-15. Fragments with an index in the range $13-15$ are considered to have high potential suitability for the conservation A. pigra, those with 9-12 moderate potential, and fragments with $\leq 8$ low potential (Table 2).

\section{Results}

A. pigra was present in 70 of the 115 vegetation fragments surveyed. We recorded 659 individuals in 118 troops, and 11 solitary individuals, giving an overall density of $95.3 \mathrm{~km}^{-2}$. Mean troop size was 5.0 \pm SE 2.6 (range 2-13), and there were 435 adults, 137 juveniles and 87 infants (Table 3 ). The most common social unit was single male-multi-female $(50$ troops, $42 \%)$, followed by multi-male-multi-female $(39,33 \%)$, single male-single female $(16,14 \%)$, and single femalemulti-male $(10,8 \%)$. The remaining $3 \%(\mathrm{n}=3)$ were same sex pairs.

The mean number of adult males per group was $1.4 \pm \mathrm{SE}$ 0.7 , with $2.0 \pm \mathrm{SE} 0.1$ adult females, $0.6 \pm \mathrm{SE} 0.1$ juvenile males, $0.6 \pm \mathrm{SE}$ 0.1 juvenile females, $0.4 \pm \mathrm{SE} 0.6$ male infants, and $0.3 \pm$ SE 0.04 female infants. Two troops had no adult males, one had no adult females and 13 had no immatures. The adult male to female ratio was $1: 1.4$, the adult female to juvenile ratio $1: 0.55$ and the adult female to immature ratio $1: 0.87$.

The distribution of A. pigra in the municipality of Catazajá is limited to low-lying areas that are prone to flooding, such as riparian vegetation, and rainforests with trees of low to medium height near the municipality of

TABLE 1 The five criteria used to generate the index of habitat potential (see text for further details) for the conservation of Alouatta pigra.

\begin{tabular}{lll}
\hline Variable & Category & Value \\
\hline Predominant vegetation & Rainforest & 3 \\
type in the fragment & Riparian vegetation & 2 \\
& Secondary vegetation & 1 \\
Fragment size & $>5 \mathrm{ha}$ & 3 \\
& $1.1-5 \mathrm{ha}$ & 2 \\
& $0.06-1 \mathrm{ha}$ & 1 \\
Distance to the & $1-200 \mathrm{~m}$ & 3 \\
nearest fragment & $201-500 \mathrm{~m}$ & 2 \\
& $>500 \mathrm{~m}$ & 1 \\
Distance to the nearest & $>5,000 \mathrm{~m}$ & 3 \\
human settlement & $1,001-5,000 \mathrm{~m}$ & 2 \\
& $0-1,000 \mathrm{~m}$ & 1 \\
Distance to the nearest & $0-500 \mathrm{~m}$ & 3 \\
water body & $501-1,000 \mathrm{~m}$ & 2 \\
& $>1,000 \mathrm{~m}$ & 1 \\
\hline
\end{tabular}

Palenque, Chiapas. Of the individual A. pigra recorded, $46.7 \%(n=308)$ were sighted in areas with riparian vegetation, $34.6 \%(\mathrm{n}=228)$ in secondary vegetation and $18.7 \%$ $(\mathrm{n}=123)$ in rainforest (Table 3$)$.

Mean fragment size was $6.01 \pm \mathrm{SE} 1.2 \mathrm{ha}$, mean distance to the nearest fragment was $112.4 \pm \mathrm{SE} 8.4 \mathrm{~m}$, and mean distance to the nearest water body was $271.5 \pm$ SE $61.5 \mathrm{~m}$. Vegetation type of $53.9 \%$ of the fragments was riparian, $37.4 \%$ was secondary vegetation and only $8.7 \%$ was rainforest. The analysis between fragments with $(\mathrm{n}=70)$ and without $(\mathrm{n}=45)$ A. pigra revealed significant differences with respect to fragment size and distances to the nearest fragment and water body $(\mathrm{P}<0.05$; Table 4$)$.

A multiple linear regression revealed no statistically significant relationship between mean troop size and fragment size and distances to the nearest fragment, human settlement or water body $\left(R^{2}=0.04, F=0.83, \mathrm{P}=0.50\right)$. A multiple linear regression of abundance and all independent variables was significant $\left(R^{2}=0.248, F=5.36, \mathrm{P} \leq 0.001\right)$ but there was a significant relationship only with fragment size $\left(R^{2}=0.253, t=3.842, \mathrm{P}<0.001\right.$; Table 5$)$.

Of the fragments in which A. pigra was found $12.9 \%$ $\left(\mathrm{n}=9\right.$; total area $\left.2.76 \mathrm{~km}^{2}\right)$ had a high index of habitat potential, $77.1 \%\left(\mathrm{n}=54 ; 3.43 \mathrm{~km}^{2}\right)$ an intermediate value and $10 \%\left(\mathrm{n}=7 ; 0.20 \mathrm{~km}^{2}\right)$ a low value (Fig. 1). Most of the fragments with low potential for conservation of A. pigra are small in area and with secondary vegetation on the edges of highways or smaller roads (Table 2).

\section{Discussion}

The density of A. pigra $\left(95.3 \mathrm{~km}^{-2}\right)$ in the fragments surveyed is similar to that reported for A. pigra in other fragmented sites such as around Palenque in Chiapas, Mexico $\left(119 \mathrm{~km}^{-2}\right)$, and the Community Baboon Sanctuary $\left(100 \mathrm{~km}^{-2}\right)$, Monkey River $\left(102 \mathrm{~km}^{-2}\right)$ and the Cockscomb Basin Wildlife Sanctuary $\left(47-257 \mathrm{~km}^{-2}\right)$ in Belize (Horwich \& Lyon, 1998; Ostro et al., 2001; Estrada et al., 2002b; Pavelka, 2003). The highest densities reported have been attributed to the crowding of $A$. pigra into small areas, where they survive as a consequence of their feeding and behavioural flexibility (Estrada et al., 2002b; Pavelka, 2003; Pozo-Montuy \& Serio-Silva, 2007). A high density of primates in disturbed areas is likely to result in a higher parasite load and greater physiological stress than would occur in preserved areas, as well as changes in foraging strategies (Stoner, 1996; Martínez-Mota et al., 2007; PozoMontuy \& Serio-Silva, 2007). However, some reports of high densities of $A$. pigra could be a result of the small number $(<30)$ of fragments surveyed (five fragments, Ostro et al., 2001; 22 fragments, Estrada et al., 2002b; 26 fragments, Rosales-Meda et al., 2007).

Mean troop size in Playas de Catazajá falls within the expected range for the species and did not vary with fragment size. This range is similar in fragmented and 
TABLE 2 Example calculations of the index of habitat potential (Table 1) for 15 of the 115 fragments surveyed in Playas de Catazajá, northeast Chiapas, Mexico (Fig. 1).

\begin{tabular}{|c|c|c|c|c|c|c|c|}
\hline Fragment & $\begin{array}{l}\text { Vegetation } \\
\text { type }\end{array}$ & Area & $\begin{array}{l}\text { Distance } \\
\text { to closest } \\
\text { fragment }\end{array}$ & $\begin{array}{l}\text { Distance to } \\
\text { closest human } \\
\text { settlement }\end{array}$ & $\begin{array}{l}\text { Distance to } \\
\text { closest water } \\
\text { body }\end{array}$ & $\begin{array}{l}\text { Index } \\
\text { of Habitat } \\
\text { Potential }\end{array}$ & Potential $^{\star}$ \\
\hline Rancho El Piñal & 3 & 3 & 3 & 2 & 3 & 14 & High \\
\hline Álvaro Obregón & 3 & 3 & 3 & 1 & 3 & 13 & High \\
\hline Cuauhtémoc Quemado & 2 & 3 & 3 & 2 & 3 & 13 & High \\
\hline El Naranjo & 2 & 3 & 3 & 2 & 3 & 13 & High \\
\hline La Paila & 3 & 3 & 3 & 1 & 3 & 13 & High \\
\hline Boca de Rio Chico & 2 & 2 & 3 & 1 & 3 & 11 & Moderate \\
\hline El Tintillo & 2 & 3 & 2 & 1 & 3 & 11 & Moderate \\
\hline Fco. J. Grajales & 2 & 1 & 3 & 1 & 3 & 10 & Moderate \\
\hline Linda Vista & 2 & 1 & 3 & 1 & 3 & 10 & Moderate \\
\hline Agua Fria & 1 & 3 & 3 & 1 & 1 & 9 & Moderate \\
\hline $\begin{array}{l}\text { Carretera al Cuyo } \\
\text { A. Obregón }\end{array}$ & 1 & 1 & 3 & 1 & 2 & 8 & Low \\
\hline $\begin{array}{l}\text { Carretera Palenque } \\
\text { a Catazajá }\end{array}$ & 1 & 1 & 3 & 2 & 1 & 8 & Low \\
\hline El Rosario A & 1 & 3 & 2 & 1 & 1 & 8 & Low \\
\hline El Rosario B & 1 & 2 & 3 & 1 & 1 & 8 & Low \\
\hline Puesto Militar de Control & 1 & 1 & 3 & 1 & 1 & 7 & Low \\
\hline
\end{tabular}

${ }^{*} \leq 8$, low potential; $9-12$, moderate potential; $13-15$, high potential

unfragmented sites (González-Kirchner, 1998; Ostro et al., 2001; Estrada et al., 2002b; Pavelka, 2003; Van Belle \& Estrada, 2005; Rosales-Meda, 2007).

There are more females than males at Playas de Catazajá, which is typical of a species with a single male-multi-female social organization. However, the number of immatures per female is low $(0.8: 1)$, as also reported for other fragmented sites in Mexico and Belize (immature: female =0.9:1 \pm SD 0.23; Horwich et al., 2001; Ostro et al., 2001; Estrada et al., 2002b; Pavelka, 2003; Pavelka et al., 2003; Pozo-Montuy et al., 2008). This suggests a decrease in reproduction compared to large areas of preserved forest such as Yaxchilán, Calakmul and Palenque National Park in Mexico and Tikal in Guatemala (immature: female 1:1.9 \pm SD 0.22; González-Kirchner, 1998; Estrada et al., 2004; Van Belle \& Estrada, 2005). The low proportion of immatures in fragmented sites could be attributed to mortality of juveniles and infants from predation (mainly by domestic dogs when monkeys descend to the ground to feed or to move between fragments; Pozo-Montuy et al., 2008), and/or to increases in malnutrition, stress and parasitic diseases as a result of crowding (Bonilla-Moheno, 2002; Martínez-Mota, 2004).

Although the social unit of $A$. pigra has been presumed to be single male-multi-female (Horwich et al., 2001), Van Belle \& Estrada (2005) found that social units are related to site size, with multi-male-multi-female social units observed with greater frequency in large protected areas and single male-multi-female groups in fragmented sites. The latter was the most frequent type of group in our study, and occurs with a similar frequency in fragmented sites in Palenque (Estrada et al., 2002a,b, 2004; Van Belle \& Estrada, 2005).

The abundance of A. pigra in Playas de Catazajá is related to fragment size, as recorded at other sites (PozoMontuy et al., 2008) and for Alouatta palliata mexicana at Los Tuxtlas, Veracruz and in northern Chiapas (Estrada \& Coates-Estrada, 1996; Anzures-Dadda \& Manson, 2007). An analysis for A. palliata mexicana suggested that the risk of extinction is lowest when the area of the fragment is maintained or increased (Escobedo-Morales, 2005). This indicates the need to preserve the remaining fragments by

TABLE 3 Total area, area surveyed and area in which A. pigra was present, and abundance, by age and sex, in Playas de Catazajá (Fig. 1).

\begin{tabular}{|c|c|c|c|c|c|c|c|c|c|c|c|c|}
\hline \multirow[b]{2}{*}{ Vegetation type } & \multirow[b]{2}{*}{ Total area $(\mathrm{ha})^{1}$} & \multirow[b]{2}{*}{ Area surveyed (ha) } & \multirow[b]{2}{*}{ Area with A. pigra (ha) } & \multicolumn{9}{|c|}{ Age and sex ${ }^{2}$} \\
\hline & & & & $\mathrm{AM}$ & $\mathrm{AF}$ & JM & JF & IM & IF & SM & SF & Total \\
\hline Secondary & 780 & 182.3 & 157.8 & 63 & 82 & 27 & 25 & 15 & 14 & 2 & 0 & 228 \\
\hline Riparian & 4,694 & 286.9 & 259.7 & 83 & 117 & 29 & 30 & 23 & 19 & 4 & 3 & 308 \\
\hline Rainforest & 428 & 222.0 & 222.0 & 31 & 48 & 11 & 15 & 10 & 6 & 1 & 1 & 123 \\
\hline Total & 5,902 & 691.2 & 639.5 & 177 & 247 & 67 & 70 & 48 & 39 & 7 & 4 & 659 \\
\hline
\end{tabular}

${ }^{1}$ Total area in the municipality

${ }^{2}$ AM, adult male; AF, adult female; JM, juvenile male; JF, juvenile female; IM, infant male; IF, infant female; SM, Solitary male; SF, solitary female 
TABLE 4 For fragments in which A. pigra were and were not located, the mean of four characteristics, determined by a geographical information system (and the non-parametric Kruskall-Wallis ANOVA between the two groups of fragments), and the number of fragments of each of the three vegetation types.

\begin{tabular}{lccc}
\hline & $\begin{array}{l}\text { Fragments with } A . \\
\text { pigra (mean } \pm \text { SE / } \\
\text { no. of fragments) }\end{array}$ & $\begin{array}{l}\text { Fragments without } \\
\text { A. pigra (mean } \pm \text { SE / } \\
\text { no. of fragments) }\end{array}$ & Kruskall-Wallis ANOVA \\
\hline Fragment size (ha) & $9.1 \pm 1.8$ & $1.1 \pm 0.2$ & $\mathrm{H}=34.841, \mathrm{df}=1, \mathrm{P}<0.001$ \\
Distance to nearest fragment (m) & $131.3 \pm 12.0$ & $83.2 \pm 9.2$ & $\mathrm{H}=8.295, \mathrm{df}=1, \mathrm{P}<0.004$ \\
Distance to nearest human settlement (m) & $909.5 \pm 143.0$ & $617.9 \pm 75.9$ & $\mathrm{H}=0.090, \mathrm{df}=1, \mathrm{P}=0.343$ \\
Distance to nearest water body (m) & $395.0 \pm 96.8$ & $79.4 \pm 28.2$ & $\mathrm{H}=12.108, \mathrm{df}=1, \mathrm{P}<0.001$ \\
Secondary vegetation & 30 & 13 & \\
Riparian vegetation & 30 & 32 & \\
Rainforest & 10 & 0 & \\
\hline
\end{tabular}

assigning them a protected status, using them only in sustainable ways, and promoting connectivity between them.

Human activities, including large-scale deforestation, agriculture and cattle ranching, are the main causes of habitat loss and fragmentation in the range of $A$. pigra in Playas de Catazajá. However, several other factors explain why we found the species in only 70 of the 115 fragments surveyed. The fragment size, distance to the nearest fragment and distance to the nearest water body were significantly different between fragments with and without $A$. pigra. Other authors have reported similar results, and attribute this to the tree composition and structural quality of the fragments for arboreal primates (Anzures-Dadda \& Manson, 2007).

Hunting by people for food, fire, extreme weather events and the history of habitat disturbance cause A. pigra to be absent in particular fragments on the Yucatan Peninsula and in Tabasco, Mexico (Watts \& Rico-Gray, 1987; SerioSilva et al., 2006; Pozo-Montuy \& Serio-Silva, 2007). We found that fragments without $A$. pigra were mainly in ejidos that are close to rivers and lagoons, where local people sometimes hunt A. pigra for food and the species is also more exposed to predation by domestic dogs and coyotes Canis latrans, particularly when moving on the ground to another fragment (Pozo-Montuy \& Serio-Silva, 2007).

The index of habitat potential is a useful tool, providing an effective instrument for making decisions and creating conservation areas, and can include any number of variables, depending on what one wishes to evaluate for particular fragments. Our data indicate that the availability of habitat is critical for A. pigra at Playas de Catazajá because only $12 \%$ of the fragments properly meet the species' needs (i.e. areas $\geq 5$ ha that are $<200 \mathrm{~m}$ to the nearest fragment and $\geq 1,000 \mathrm{~m}$ from roads and settlements). Using these data we can now guide conservation efforts for forest fragments. For example, fragment size could be increased, habitat restored, connectivity with other fragments established, and environmental education programmes could be developed and taken to the settlements near those fragments with the greatest potential for conservation of the species.

Through the establishment of environmental education programmes, local people, researchers and authorities could join together in efforts to use fragments with conservation potential as a sanctuary for A. pigra. Fragments with low to moderate conservation potential could be incorporated into a conservation plan based on community ecotourism, with A. pigra the flagship species for Playas de Catazajá. This strategy has been successfully applied elsewhere for other primate species (Horwich, 1998; Horwich \& Lyon, 1998; Goldsmith, 2001; Serio-Silva, 2006) but prior to any implementation it will be necessary to evaluate an area's potential for ecotourism and any threats this may represent for the species (Grossberg et al., 2003; Bonilla-Sánchez, 2006). The study reported here has been used as supporting evidence

TABLE 5 Evaluation of the relationships of abundance and mean troop size of A. pigra with area of fragment and distances to the nearest fragment, nearest human settlement and nearest water body. The only significant relationship is in bold.

\begin{tabular}{|c|c|c|c|c|c|}
\hline Independent variable & Dependent variable & Coefficient $\left(R^{2}\right)$ & SE & $t$ & $\mathrm{P}$ \\
\hline \multirow[t]{2}{*}{ Area } & Abundance & 0.253 & 0.0659 & 3.842 & $<\mathbf{0 . 0 0 1}$ \\
\hline & Mean troop size & 0.0230 & 0.0143 & 1.601 & 0.114 \\
\hline Distance to nearest & Abundance & -0.0120 & 0.0100 & -0.200 & 0.235 \\
\hline fragment & Mean troop size & -0.00131 & 0.00218 & -0.602 & 0.550 \\
\hline Distance to nearest & Abundance & 0.00134 & 0.000691 & 1.933 & 0.058 \\
\hline human settlement & Mean troop size & 0.0000547 & 0.000150 & 0.364 & 0.717 \\
\hline Distance to nearest & Abundance & -0.0000159 & 0.00125 & -0.0127 & 0.990 \\
\hline water body & Mean troop size & -0.0000667 & 0.000271 & -0.246 & 0.806 \\
\hline
\end{tabular}


for the classification of the Playas de Catazajá wetlands as a conservation area and its decree as a RAMSAR site at the behest of the Instituto de Historia Natural y Ecología and the government of the state of Chiapas (CONANP, 2008).

\section{Acknowledgements}

We are grateful to the inhabitants of Playas de Catazajá, Chiapas, Mexico for their invaluable assistance as field guides, Patricia Moreno, Luciana Porter and Laura T. Hernández for suggestions, and Bianca Delfosse for linguistic assistance. The Instituto de Ecología A.C. and IDESMAC A.C. provided financial and logistical support. We thank CONACYT for a scholarship (\#190320) awarded to YMBS.

\section{References}

Anzures-Dadda, A. \& Manson, R.H. (2007) Patch-and landscape-scale effects on howler monkey distribution and abundance in rainforest fragments. Animal Conservation, 10, $69-76$.

Ascencio, N., Arroyo-Rodríguez, V., Dunn, C.J. \& Azkarate, C.J. (2009) Conservation value of landscape supplementation for howler monkeys living in forest patches. Biotropica, 46, 768-773.

Berovides-Álvarez, V. (2000) Método de valoración de la fauna para el ecoturismo. Biología, 14, 108-113.

Bonilla-Moheno, M. (2002) Prevalencia de parásitos gastroentéricos en primates Alouatta pigra $y$ Ateles geoffroyi yucatanensis localizados en zonas conservadas y fragmentadas del estado de Quintana Roo, Mexico. BSc thesis, Universidad Nacional Autónoma de Mexico, Mexico DF, Mexico.

Bonilla-Sánchez, Y.M. (2006) Evaluación de la distribución y abundancia del mono aullador negro (Alouatta pigra) identificando áreas potenciales para ecoturismo y conservación en Playas de Catazajá, Chiapas. MSc thesis, Instituto de Ecología AC, Xalapa, Mexico.

Cayuela, L. (2006). Deforestación y fragmentación de bosques tropicales montanos en los Altos de Chiapas, Mexico. Efectos sobre la diversidad de árboles. Ecosistemas, 15, 192-198.

Challenger, A. (1998) Utilización y conservación de los ecosistemas terrestres de Mexico. CONABIO, Instituto de Biología, Sierra Madre, Mexico.

CITES (2009) The Convention on International Trade in Endangered Species of Wild Fauna and Flora, The Species. Http://www.cites. org/eng/disc/number_species.pdf [accessed 5 June 2009].

CONAP (2001) Listado de especies de fauna silvestre amenazada de extinción (Lista Roja de Fauna). Resolución Secretaria del CONAP ALC/032-99. Documento de Políticas y Normativos No. 10. CONAP-IDEADS, PROARCA-CAPAS, Guatemala.

CONANP (2008) Comisión Nacional de Áreas Naturales Protegidas. Http://www.conanp.gob.mx [accessed 11 June 2008].

Escobedo-Morales, L. (2005) Estimación de la viabilidad metapoblacional del mono aullador en un paisaje altamente fragmentado en los Tuxtlas Veracruz, Mexico. MSc thesis, Instituto de Ecología AC, Xalapa, Mexico.

Estrada, A., Castellanos, L., García, Y., Franco, B., Muñoz, D., IbARRA, A. et al. (2002a) Survey of the black howler monkey (Alouatta pigra) population at the Mayan site of Palenque, Chiapas, Mexico. Primates, 44, 51-58.
Estrada, A. \& Coates-Estrada, R. (1996) Tropical rain forest fragmentation and wild populations of primates at Los Tuxtlas, Mexico. International Journal of Primatology, 17, 759-783.

Estrada, A., Luecke, L., Van Belle, S., Barreta, E. \& Rosales-Meda, M. (2004) Survey of black howler (Alouatta pigra) and spider (Ateles geoffroyi) monkeys in the Mayan sites of Calakmul and Yaxchilán, Mexico and Tikal, Guatemala. Primates, 45, 33-39.

Estrada, A., Mendoza, A., Castellano, L., Pacheco, R., Van Belle, S., García, Y. \& Muñoz, D. (2002b) Population of the black howler monkey (Alouatta pigra) in a fragmented landscape in Palenque, Chiapas, Mexico. American Journal of Primatology, $58,45-55$.

Goldsmith, M. (2001) Effects of ecotourism on the behavioral ecology of Bwindi gorillas, Uganda: preliminary results. American Journal of Physical Anthropology, 30, 161.

GonZaLez-KirChNER, J.P. (1998) Group size and population density of the black howler monkey (Alouatta pigra) in Muchukux forest, Quintana Roo, Mexico. Folia Primatologica, 69, 260-265.

Grossberg, R., Treves, A. \& Naughton-Treves, L. (2003) The incidental ecotourist: measuring visitor impacts on endangered howler monkeys at a Belizean archaeological site. Environmental Conservation, 30, 40-51.

HoRWICH, R. (1998) Effective solutions for howler conservation. International Journal of Primatology, 19, 579-598.

Horwich, R.H., Brockett, R.C., James, R.A. \& Jones, C.B. (2001) Population growth in the Belizean black howler monkey (Alouatta pigra). Neotropical Primates, 9, 1-7.

Horwich, R.H. \& Lyon, J. (1998) A Belizean Rain Forest. The Community Baboon Sanctuary. Orang-utan Press, Gays Mills, Wisconsin, USA.

IUCN (2008) 2008 IUCN Red List of Threatened Species. IUCN, Gland, Switzerland. Http://www.iucnredlist.org [accessed 30 April 2009].

Marsh, L. (2003) Primates in fragments. In Primates in Fragments: Ecology and Conservation (ed. L.K. Marsh), pp. 6-7. Kluwer Academic/Plenum Publishers, New York, USA.

Martínez-Mota, R. (2004) Niveles de cortisol fecal en monos aulladores negros (Alouatta pigra) en dos tipos de hábitat en el sur de Mexico. MSc thesis, Instituto de Ecología AC, Xalapa, Mexico.

Martínez-Mota, R., Valdespino, C., Sánchez-Ramos, M.A. \& SERIO-SILVA, J.C. (2007) Effects of forest fragmentation on the physiological stress response of black howler monkeys. Animal Conservation, 10, 374-379.

NOM-059-SEMARNAT (2001) Norma Ecológica Mexicana; Protección ambiental-Especies nativas de Mexico de flora y fauna silvestres-Categorías de riesgo y especificaciones para su inclusión, exclusión o cambio-Lista de especies en riesgo. D.F., Mexico.

Ostro, L.E.T., Silver, S., Koontz, F.W., Horwich, R. \& BRoскеTT, R. (2001) Shifts in social structure of black howler (Alouatta pigra) groups associated with natural and experimental variation in population density. International Journal of Primatology, 22, 733-748.

PavelKa, M.S.M. (2003) Group, range, and population size of Alouatta pigra at Monkey River, Belize. Neotropical Primates, 11, 187-191.

Pavelka, M.S.M., Brusselers, O., Nowak, D. \& Behie, A.M. (2003) Population reduction and social disorganization in Alouatta pigra following a hurricane. International Journal of Primatology, 24, 1037-1055.

Pennington, T.D. \& Sarukhán, J. (1998) Árboles Tropicales de Mexico. Manual para la identificación de las principales especies. Ediciones Científicas Universitarias, Serie Texto Científico Universitario, Universidad Autónoma de Mexico, Fondo de Cultura Económica, D.F., Mexico. 
Pozo-Montuy, G. \& Serio-Silva, J.C. (2007) Movement and resource use by a group of Alouatta pigra in a forest fragment in Balancán, Mexico. Primates, 48, 102-107.

Pozo-Montuy, G., Serio-Silva, J.C., Bonilla-Sánchez, Y.M., Bynum, N. \& LANDGRAve, R. (2008) Current status of the habitat and population of the black howler monkey (Alouatta pigra) in Balancán, Tabasco, Mexico. American Journal of Primatology, 70, 1-8.

Rodríguez-Toledo, E.M., Mandujano, S. \& García-Orduña, F. (2003) Relationships between forest fragments and howler monkeys (Alouatta palliata mexicana) in southern Veracruz, Mexico. In Primates in Fragments: Ecology and Conservation (ed. L.K. Marsh), pp. 79-97. Kluwer Academic/Plenum Publishers, New York, USA.

Rosales-Meda, M., Estrada, A. \& Lopez, E.J. (2007) Demographic survey of black howler monkey (Alouatta pigra) in the Lachuá Eco-Region in AltaVerapaz, Guatemala. American Journal of Primatology, 69, 1-9.

Serio-Silva, J.C. (2006) Las Islas de los Changos (The Monkey Islands): the economic impact of ecotourism in the region of Los Tuxtlas, Veracruz, Mexico. American Journal of Primatology, 68, $1-8$.

Serio-Silva, J.C., Rico-Gray, V. \& Ramos-Fernández, G. (2006) Mapping primate populations in the Yucatan Peninsula, Mexico: a first assessment. In New Perspectives in the Study of Mesoamerican Primates: Distribution, Ecology, Behavior and Conservation (eds A. Estrada, P.A. Garber, M.S.M. Pavelka \& L.G. Leucke), pp. 513-538. Springer Press, New York, USA.

Stoner, K. (1996) Prevalence and intensity of intestinal parasites in mantled howling monkeys (Alouatta palliata) in north-eastern Costa Rica; implications for conservation biology. Conservation Biology, 10, 539-546.

Stuart, M.D., Greenspan, L.L., Glander, K.E. \& Clarke, M. (1990) A coprological survey of parasites of wild mantled howling monkeys, Alouatta palliata palliata. Journal of Wildlife Disease, 26, 547-549.

Van Belle, S. \& Estrada, A. (2005) Cambios demográficos en poblaciones del mono aullador negro (Alouatta pigra) como consecuencia de la fragmentación del hábitat. Universidad y Ciencia, Número especial II.

Watts, E. \& Rico-Gray, V. (1987) Los primates de la península de Yucatán, Mexico: estudio preliminar sobre su distribución actual y estado de conservación. Biotica, 12, 57-66.

WPA (200o) Wildlife Protection Act. Belize Government. Http:// www.belizelaw.org/lawadmin/index2.html [accessed 13 June 2009].

Zunino, G., Kowalevsky, M., Oklander, L.I. \& Gonzalez, V. (2007) Habitat fragmentation and population size of the black and gold howler monkey (Alouatta caraya) in a semi-deciduous forest in Northern Argentina. American Journal of Primatology, 69, 966975 .

\section{Biographical sketches}

YAdiRa M. Bonilla-SÁnChez is currently studying the demography, feeding ecology and behaviour of A. pigra in Eucalyptus plantations in southern Mexico. Juan Carlos Serio-Silva's main interests are in ecology, behaviour and conservation of Mexican primates and in training a new generation of Mexican primatologists to apply their skills to increase the effectiveness of primate conservation in Mesoamerica. Gil B ER T o Pozo-Mont Uy is applying conservation strategies for the protection of primates in south-eastern Mexico. His interests are in the study of ecological and conservation aspects of neotropical primates and other arboreal mammals in fragmented landscapes. NORA B YNU M's current research interests include seasonality and phenology of tropical canopy trees, particularly in relation to global change. 